\title{
Artificial insemination with the husband's semen after the husband's death
}

\author{
D J Cusine Department of Private Law, University of Aberdeen
}

\begin{abstract}
Artificial insemination using the husband's semen $(A I H)$ has always seemed more acceptable than the same procedure using donor semen. However, the layman may not even have thought of the legal problems or the moral dilemma if in fact a woman is inseminated using her husband's frozen semen after his death. In the USA there are already sperm banks set up by private individuals, generally for the use of those marriage partners when the husband has had a vasectomy and afterwards a child is desired. If such private sperm banks were set up in Britain complex legal problems would follow, quite apart from the moral issue as to whether it was desirable to bring a child into the world deliberately having deprived him of a father from the start. These are the issues which $\mathrm{Mr}$ Cusine thinks should be carefully considered before doctors, lawyers and the women potentially concerned are confronted with a new dilemma.
\end{abstract}

In recent years there has been considerable discussion of the legal and ethical issues raised by the practice of human artificial insemination, particularly artificial insemination using donor semen (AID), and the most recent development is a Bill introduced by Miss Joan Lester MP on the status of children born as a result of AID.

Much of that discussion has centred on AID simply because there are fewer issues raised by artificial insemination using the husband's semen (AIH) but one problem of AIH which has not as yet been ventilated is the possibility that by preserving his sperm a man may father children after his death.

The Departmental Committee on Human Artificial Insemination ${ }^{1}$ (the Feversham Committee) (1960) included within its report, the following paragraph:-

'Some of our witnesses have drawn attention to the possibility that if it became practicable to preserve human sperm for more than a few hours a woman might be artificially inseminated with her husband's semen after his death ... ' (para IIO).

Assuming for the moment that this is possible, it raises the question of the status of such a child and the desirability of the practice. Although at the time of the Feversham Committee's report, it was said to be possible to preserve human sperm for only a few hours (para 68) they expressed an opinion on both of these issues. In the first place, they were of the view that the child would be illegitimate because the husband's death would have terminated the marriage and for that reason, they considered such a practice 'most undesirable' because the child would be deprived of a father from the start. Their view was that there would be 'no justification for bringing a child into the world .in such circumstances' (para IIO).

\section{Status of a child born of AIH}

I should like to develop these two points a little further. At present, one could say that a child is legitimate if it is conceived or born during the subsistence of a valid marriage. A similar statement would be that a child is legitimate if it was conceived by the semen of a women's husband. These two statements were at one time identical and diverge only if it is possible to preserve human sperm after the husband's death. The death of the husband would put an end to the marriage and so it could be argued that any child conceived thereafter would be illegitimate. However, one must examine the reasoning behind such a statement. The reason why a child born after the husband's death may be declared illegitimate is that such a period has elapsed since the death as to exclude the possibility that the husband is the father. Proof of adultery is another way of showing that the husband could not be the father. If the argument is correct, it follows that to say that a child is illegitimate where it has been conceived after the husband's death, but with his semen, involves reasoning different from that outlined above. On the other hand, to say that such a child is legitimate means that the concept of legitimacy must be defined in terms other than that of marriage or that the definition of marriage must be reframed to include the possibility of a wife conceiving a child after her husband's death. 'Till death us do part' is no longer sufficient.

Whether such a child is legitimate or illegitimate is clearly important, but for many purposes the distinctions between legitimate and illegitimate children have been abandoned, particularly in the field of succession ${ }^{2,3}$. Where the husband's sperm has been frozen and so there is a possibility that his widow may continue to conceive his children, does it follow that his estate cannot be wound up until either she has de facto reached an age beyond which she cannot bear children or has remarried? 
The reason why the Feversham Committee did not develop their views was that in 1960 it was thought to be impossible to preserve human sperm for any length of time. Such a reason is no longer valid; it is now, and has been for some time, possible (in fact since well before 1960$)^{4}$ to freeze human sperm. ${ }^{5}$ In Britain, this is done only in connexion with artificial insemination, but it has been observed that sperm frozen for up to three years has produced a pregnancy ${ }^{6}$ and sperm has been frozen for ro years with no significant loss of motility. ${ }^{7}$

\section{Effect on a child deprived of a father from the start}

The second issue, and indeed the more important, is whether such a practice is desirable. The Feversham Committee thought that to produce a child who was deprived of a father from the start was not justified.

Sperm banks exist in Great Britain only in institutions which practice artificial insemination where the sperm of donors is preserved (some of whom, although not many are candidates for vasectomy), but when the issue was raised again in 1974 by a working party of the British Association for the Advancement of Science, it was pointed out that 'as current laws and regulations stand in Britain there is nothing to prevent a sperm bank being set up by private individuals.' ${ }^{8}$ In the USA, however, sperm banks have been in existence for some time, chiefly for use by those who are about to undergo vasectomy. The man will deposit his semen so that if he changes his mind and wishes to have children, or more children, or if his wife or children die, he is still able to have a family. In Science, the journal of the American Association for the Advancement of Science, there was a report in I972 on the setting up of a sperm bank, for personal use rather than for donor insemination. The report was as follows, 'How do you make a deposit at a sperm bank? At Idant Corporation, a rapidly growing young company that opened a branch in suburban Baltimore, Maryland, a few weeks ago, the procedure is simple.

'The customer need only have observed at least 48 hours of prior continence - to ensure a higher sperm count - to qualify as a depositor. He strolls into Idant's small laboratory, which is manned only by a secretary and a hospital biologist, fills out a form and plonks down the $\$ 80$ fee required for the processing and freezing of three semen specimens. He then retreats to a tiny room furnished with a comfortable armchair, two pornographic magazines and an ashtray. (He may drop off his sample on the way to work providing it is less than two hours old at the time of deposit.) The ejaculate is examined, diluted by a glyerol preservative and stored in 12 or 15 little vials resembling ball point pen refills.
The vials are stored in three metal cannisters and submerged in stainless steel barrels filled with? liquid nitrogen which bubbles at its boiling poin of $-196^{\circ} \mathrm{C} .^{9}$

It has been estimated that the cost of setting up $\underset{\mathrm{a}}{\mathrm{C}}$ sperm bank for the purposes of donor insemination could be as low as $£$ 1400 but even on a large scale the cost probably would not exceed $£ 5500$. Pre $\Omega$ sumably the cost of a 'personal' bank would be thes same. ${ }^{5}$

If such a bank were set up in Britain, we couldbe faced with the possibility of children conceivedw after the husband's death, and the complex lega? issues arising therefrom.

However, the question remains whether such $\dot{\alpha}$ practice is desirable. In the opinion of the Feversham ${ }^{+}$ Committee it was not because the child would begr deprived of a father from the start. In one sense ${ }_{0}^{\omega}$ the child would not be in any different a position? from the posthumous child at present, but unlike such a child, the child conceived with the husband'so sperm after his death would be deliberately con $\stackrel{\infty}{=}$ ceived, thus intentionally creating a one-paren family. The Finer Committee Report evidences the difficulties which can face such families and these provide a strong case against intentionally increasing their numbers.

On the other hand, it can be said that few if any? women would be inseminated in this way withoue considering fully the implications of such an act, particularly the child's upbringing.

The basic issue is what disadvantages, if any, a child suffers if it does not have a father and these must be investigated before any decision is made about control over such a practice.

Given that human sperm can now be preserved. for considerable periods and that there is nothing to prevent the setting up of a 'personal' sperm bank s. $^{\mathrm{D}}$ the time is more than ripe for such an investigation and a discussion of the implications of deliberately creating a one-parent family by the artificial insemination of a woman with her husband's semen after his death.

\section{References}

${ }^{1}$ Report of the Departmental Committee on Human Artifical Insemination ("The Feversham Committee") 1960 Cmnd. 1105.

${ }^{2}$ Meston, M C (1969). The Succession (Scotland) Act్ 1964 (2nd ed) esp 70-2. Edinburgh: W Green \& Son Ltd.

${ }^{3}$ Miller, J G (1977). The Machinery of Succession, 105-8. Abingdon, Oxon: Professional Books. Scots lawi would appear to be more favourably disposed to illegitimate children.

"Richardson, D W (1975), Artificial Insemination in the? Human in modern trends in Human Genetics $19750^{\circ}$ 2 Chapter 13.

${ }^{5}$ Brudenell, J M - other (1977). Artificial Insemination 97 et seq. London: Royal College of ObstetriciansO \& Gynaecologists. 
'Jackson, M C M and Richardson, D W (1977). The Use of Fresh and Frozen Semen in Human Artificial Insemination, fournal of Biosocial Science, 9, 25I-26I.

'Sherman, J K (1973), Synopsis of the Use of Frozen Human Semen Since 1964: State of the Art of Human Semen Banking, Fertility, Sterility, 24, 397-420.
${ }^{8}$ Bodmer, W F and Jones, A (1974). 'Our Future Inheritance, Choice or Chance?', I7.

${ }^{2}$ Holden, C (1972). 'Sperm Banks Multiply as Vasectomies Gain Popularity', Science 176, 32. Brudenell and others supra III.

${ }^{10}$ Report of the Committee on One-Parent Families (1974) Cmnd. 5629 esp para 8, 15. 